\title{
MEMBANGUN KINERJA PROFESIONAL DALAM ORGANISASI PUBLIK
}

\author{
Oleh : \\ Rosidah \\ FISE UNY
}

\begin{abstract}
Abstrak
Dalam membangun kinerja profesional dalam organisasi publik salah satunya adalah meningkatkan produktivitas kerja yang berkualitas pada aparatur pemerintah. Upaya tersebut mengandung konsekuensi bahwa pemerintah perlu membuat aturan yang mampu memicu dan mendorong aparatur berperilaku mengarah pada kualitas yang diharapkan. Beberapa hal terkait dengan itu, maka jajaran kepemimpinan perlu kiranya mensosialisasikan dan menerapkan dalan kinerja sehari-hari Keputusan Menteri PAN No. 25/Kep/M.Pan/4/2002 tentang Pedoman Pengembangan Budaya Kerja Aparatur Negara, yang sarat dengan nilai-nilai moral, yang harus ditegakkan, antara lain adanya: komitmen dan konsistensi, integritas dan profesional, kebersamaan dan dinamika kelompok kerja, disiplin dan keteraturan kerja, - keikhlasan dan kejujuran. Di samping itu kiranya perlu mengevaluasi kembali Daftar Penilaian Prestasi Pegawai (DP3), yang selama ini terkesan formalitas serta pedoman Pemberian Penghargaan kepada aparatur yang mampu memberikan pendorong untuk meningkatkan prestasi kerja.
\end{abstract}

Key word: prestasi kerja, organisasi publik

\section{Pendahuluan}

Dalam kerangka Negara yang demokratis, masyarakat atau rakyat mempunyai hak untuk menentukan adanya penyelenggaraan pemerintahan melalui wakil-wakilnya di lembaga legislatif. Dengan begitu pemerintah harus memenuhi kehendak rakyat agar mereka hidup damai, aman dan sejahtera di bumi Indonesia. Apabila dikaitkan dengan kinerja pemerin- tahan maka pemerintah dalam hal ini aparatur pemerintah harus dapat memenuhi apa yang menjadi tuntutan masyarakat; ketika mereka berurusan dengan lembaga pemerintahannya. Sebagai konsekuensinya maka budaya kerja profesional dari para aparaturnya perlu dieksiskan guna melakukan pelayanan kepada rakyat. Untuk itu perlu membangun kinerja profe- 
sional dalam laingkup negara yang demokratis

Pemerintah melalui Keputu-san Menteri Pendayagunaan Apa-ratur Pemerintah No.25/Kep/Men/ M.Pan/4/2002 tentang Pedoman Pengembangan Budaya Kerja Aparatur Negara meliputi berbagai aspek, yang antara lain: komitmen dan konsistensi, wewenang dan tanggungjawab, keikhlasan dan kejujuran, integritas dan profesional, kepemimpinan dan keteladanan, dil. Nampaknya berbagai aspek yang termaktub dalam Kep.men. tersebut sarat dengan nilai-nilai yang harus ditegakkan dan dipraktekkan oleh apartur pemerintah. Dalam definisi etika administrasi negara maka aktivitas-aktivitas teknis penyelenggaraan pemerintahan negara akan selalu mempunyai konsekuensi nilai (value loaded). Hal tersebut ditegaskan oleh Wahyudi Kumorotomo (1992) bahwa proses administrasi negara senantiasa menuntut pertangungjawaban etis. Namun pada kenyataannya sangat sedikit aparatur yang mengetahui hal tersebut. Pada umumnya para apartur bekerja dalam rutinitas yang seoleh-oleh lepas dari nilai-nilai yang harus melekat pada masing-masing pribadinya. Apabila nilainilai yang mengandung budaya kerja profesional tidak eksis dalam suasana kerja/kinerja akan cenderung tidak menjadikan tali penguat sebagai beteng untuk bertindak menyimpang atau melakukan hal-hal yang tidak mendukung budaya kerja profesional.
Sebagaimana diketahui bersama bahwa apa yang menjadi kewajiban aparatur dalam bekerja adalah melakukan pekerjaan seperti yang tercantum dalam job diskripsi atau sesuai dengan batas pelimpahan tugas dari atasannya. Dalam hal tersebut adakalanya didalam juklak tidak dilengkapi dengan nilai-nilai moral yang harus pula ditegakkan dalam melakukan pekerjaannya. Nilai-nilai yang menyertai dalam hasil kerja dituangkan secara terpisah dalam kepmen ataupur peraturan pemerintah sehingga menyebabkan hasil pekerjaan kemungkinan menyimpang dari nilai-nilai moral. Atau dengan kata lain bahwa secara phisik hasil kerjanya bagus namun secara nurani barangkali sarat/terkontaminasi dengan perilaku yang menyimpang tata aturan birokrasi/ mal praktek ditinjau dari sisi penilaian moral. Meskipun sesungguhnya telah ada beberapa aturan moral yang sudah diucapkan dalam sumpah jabatan ataupun yang ada dalam peraturan pemerintah/ kepmen, namun apabila hal tersebut tidak selalu dieksiskan dalam kerja atau menjadi bagian yang terpisah kadang memberikan ruang untuk melakukan penyimpangan-penyimpangan

/praktik patologi birokrasi. Oleh karena itu sebagai salah satu solusinya antara lain dengan upaya membangun kinerja yang profesional melalui sosialisasi yang terus 
menerus terkait dengan nilai-nilai yang harus ditegakkan/dimplementasikan atau menjadi bagian yang tidak terpisahkan dalam budaya kerja. Dengan kata lain bahwa para aparatur harus menjunjung tinggi Etika Administrasi Negara.

Dalam membangun kinerja profesional maka Etika administrasi Negara perlu ditegakkan, namun di sisi lain sebagai stimulus untuk mengimplementasikan etika tersebut sehingga menjadi budaya kerja/pola perilaku sehari-hari maka yang tidak kalah penting diperhatikan adalah permasalahan yang terkait dengan bagaimana kebijakan pemerintah dibangun/ditetapkan dalam kerangka memberikan penilaian/pengawasan, penghargaan dan sangsi yang mampu memberikan parameter akan kualitas aparatur. Dalam hal penilaian pegawai sebagaimana masih digunakan untuk menentukan karir pegawai, selama ini masih menggunakan DP3 (Daftar Penilaian Pelaksanaan Pekerjaan), sebagaimana diatur dalam UU No.8 tahun 1974 tentang Pokok-Pokok Kepegawaian. Namun dalam esensinya masih banyak aspek yang perlu mendapat perhatian supaya fungsi evaluasi pegawai menuju pada sasarannya.

Memahami Daftar Penilaian Pekerjaan Pegawai (DP3) \& Pemberian Penghargaan

Dalam rangka meningkatkan kinerja yang profesional, maka selayaknya sudah harus dievaluasi kembali perangkat yang mengatur penilaian prestasi pegawai. Rasionalitas adanya evaluasi tersebut karena ketepatannya perlu disangsikan. Penilaian terhadap pegawai sebagaimana diatur dalam DP3 nampak hanya mempunyai nilai formalitas dalam pelaksanaannya. Di samping itu tidak mempunyai daya beda serta pemicu untuk mendorong para pegawai kompetitif terhadap kualitas kinerjanya. Kalau diamati indikator penilaian yang ada dalam daftar penilaian (DP3) sesengguhnya sudah mencakup aspek penilaian kualitas, tetapi dalam hal teknis pelaksanaannya kurang memberikan hasil yang optimal sebagai alat pengukur kualitas aparatur pemerintah.

Tidak saja pemberian penilaian terhadap kualitas kerja yang perlu ditinjau ulang, Permasalahan terkait dengan pemberian penghargaan kepada aparatur rupanya juga banyak yang perlu dievaluasi. Selama ini bentuk dan mekanisme penghargaan kurang terumus dengan baik. Pemberian penghargaan, yang selama ini sudah diberikan, misalnya: Satya Lencana Kemerdekaan, Satya Lencana Pembangunan, Satya Lencana Wira Karya, Satya Lencana Karya Satya, dll. Namun diantara penghargaan tersebut tidak ditanggapi oleh pegawai sebagai suatu penghargaan dari hasil prestasinya dan kurang memberikan manfaat. Bentuk peng- 
hargaan tersebut bukan merupakan penghargaan yang memberikan nuansa dan rangsangan untuk terjadinya pengembangan diri. Penghargaan yang diberikan bukan dilandasi oleh penilaian prestasi. Jadi fungsi penghargaan belum mampu. Memenuhi esensi dari tujuan penilaian yakni mengangkat kualitas kinerja yang profesional.

Pemberian penghargaan bagi pegawai, sangat erat keitannya dengan etika birokrasi di Indonesia, baik yang telah diformalkan lewat ketentuan dan peraturan kepegawaian ataupun tidak Etika birokrasi merupakan bagian dari aturan main dalam organisasi birokrasi atau pegawai negeri yang dikenal sebagai Kode Etik Pegawai Negeri atau disebut Sapta Prasetya Korps Pegawai Republik Indonesia (Sapta Prasetya KORPRI), yang salah satunya mengatur tentang pemberian penghargaan dan sanksi/hukuman bagi Pegawai Negeri Sipil, yang berbunyi: "Kepada Pegawai Negeri dapat diberikan penghargaan apabila telah menunjukkan kesetiaan dan prestasi kerja dan memiliki etika kerja yang baik, dianggap berjasa bagi negara dan masyarakat perlu diberikan penghargaan kepada Pegawai Negeri yang bersangkutan berupa tandan jasa, kenaikan pangkat istimewa yang secara otomatis kenaikan gajinya sesuai pangkat, dengan harapan agar menjadi contoh kepada yang lain dalam melaksanakan tugas" (Undang Undang Kepegawaian,
2003). Tujuan yang paling penting dalam pemberian penghargaan adalah terciptanya suatu sistem yang adil dalam pemberian bentuk kompensasi. Keadilan yang diharapkan dapat dinilai paling tidak dari tiga dimensi, yaitu :

1. Internal Equity

Tingkat imbalan yang diberikan oleh lembaga sudah adil untuk setiap jabatan yang ada di dalam organisasi.

\section{External Equity}

Imbalan yang diberikan kepada karyawan oleh suatu organisasi sudah adil bila dibandingkan dengan imbalan yang diberikan oleh organisasi lain sejenis dalam job yang sama..

3. Individual Equity

Imbalan yang diberikan kepada karyawan tersebut sudah adil bila dibandingkan dengan imbalan yang diberikan kepada orang lain dalam pekerjaan yang sama atau sejenis

Untuk mewujudkan pengembangan dan pengendalian pegawai yang efektif, dán pada akhirnya pada peningkatan kinerja maka diperlukan instrumen penghargaan dengan penetapan bentuk serta mekanisme yang jelas dan akuntabel. Yaitu sistem pemberian penghargaan yang didasarkan atas penilaian secara obyektif dengan kriteria yang jelas, diikuti oleh azas keadilan. Namun sebaliknya, penghargaan kurang memacu semangat manakala ada kesan, misalnya untuk 
formalitas saja, ădanya ketidakjelasan kriteria, adanya unsur hallo effect, pertemanan, dan lain-lain.

Penilaian kinerja mempunyai peran penting daląm strategi pengembangan pegawai, salah satunya dapat digunakan sebagai dasar pertimbangan untuk keputusan pemberian penghargaan, promosi, mutasi, training, pemberhentian, dll Daftar Penilaian Pelaksanaan Pekerjaan (DP3) dalam UU No.8 tahun 1974 tentang Pokok-Pokok Kepegawaian dan dikuatkan dengan PP RI No. 10 tahun 1974 tentang penilaian pelaksanaan pekerjaan PNS, disebutkan bahwa yang digunakan untuk menilai kinerja PNS adalah dengan DP3. tetapi dalam pelaksanaannya ada beberapa kelemahan: 1) penilaian aparatur melalui DP3 hanya dilakukan sèkali dalam satu tahun, di setiap akhir tahun, 2) proses penilaian kinerja PNS, DP3 hanya merupakan produk akhir, sehingga jarang dimanfaatkan kecuali untuk kenaikan pangkat dan promosi, belum dijadikan untuk bahan rekomendasi pemberian penghargaan, 3).perilaian kinerja tidak didasarkan pada hasil analisa jabatan, sehingga sering dianggap tidak proporsional, 4) unsusr subyektivitas sangat memungkinkan untuk muncul dalam penilaian tersebut.

Standar Pedoman Pemberian Penghargaan Pegawai yang sehat akan mampu memberikan penilaian kinerja pegawai dan akan mempermudah melakukan pengembangan pegawai. Pedoman tersebut memberikan motivasi pegawai untuk peningkatan produktivitas kerja dan mampu mengidentifikasi pegawai yang potensial. Adanya Standar Pedoman tersebut juga memberikan kemudahan dalam penilaian dan pertanggungjawaban pada pegawai dalam kepemimpinan organisasi. Sehingga dalam rangka pengembangan kualitas pegawai dan lembaga, yang selanjutnya berimplikasi terhadap peningkatan pembangunan, penyelenggaraan pemerintahan dan pelayanan dapat terealisir.

\section{Pentingnya Etika Administrasi Negara Dalam Penyelenggaraan Pemerintahan}

Suatu persoalan yang tidak kunjung selesai mulai dari korupsi sampai dengan kurangadanya semangat pegawai dalam menjalankan fungsinya sebagai aparatur pemerintahan memberikan perhatian dalam upaya meningkatakan kinerja profesional dalam pemerintahan di negara ini. Merevisi kembali bentuk-bentuk penyalahgunaan wewenang yang terkait dengan perilaku korupsi/mal administrasi lainnya dapat melalui penegakan moral dalam budaya kerja. Meskipun masalah pendekatan moral kerja - tidak sebagai hal yang baru ketika berbicara pengurangan mal administrasi, misalnya, namun seolah bukan menjadi obat yang mujarab. Salah 
satu sebab barangkali disinyalir karena kinerja profesional tidak men-jadi slogan yang harus diimplementasikan ataupun belum menjadi misi dalam jajaran unit kerja. Psnyebab lain barangkali adalah ketidak-tahuan aparatur terkait dengan berba-gai aturan tentang nilai-nilai moral yang perlu diterapkan dalam dunia kerjanya.

Nilai-nilai di atas pertu disosialisasikan secara terus menerus dalam suasana kerja. Upaya memberikan pemahaman perlu dilakukan kepada para pegawai memalui berbagai momen yang kiranya tepat dalam kondisi yang sedang berlangsung. Contohcontoh riil perlu ditunjukkan pada pegawainya. Beberapa poin yang dirasa perlu untuk dijelaskan, diantaranya :

\section{Komitmen dan Konsistensi}

Nilai ini sangat penting dieksiskan dalan susasana kerja. Komitmen dan konsisten merupakan dua kata yang hampir mempunyaui arti sepadan. Komitmen artinya keteguhan melakukan aturan main yang ada atau taat asas; adanya kesetiaan dan ketulusan dalam melakukan kerja, sehingga merasa ikhlas bekerja. Adanya keikhlasan tersebut mendorong orang untuk lebih besemangat dan tanpa pamrih. Kesadaran ini perlu ditumbuhkan pada diri pegawai. Dalam menumbuhkan tentu saja tidak secara paksa namun perlahan akan tetapi akan ada perubahan. Pendekatan personal pun kadang diperlukan karena masing-masing pegawai mempunyai karakter yang berbeda. Adapun konsisten mempunyai arti terus menerus (dalam jangka panjang) selalu dalam kondisi yang diharapkan. Adanya komitmen dan konsisten pada pencapaian misi dan visi organisasi, misalnya, memungkinkan para pegawai bekerja tidak menyimpang dari tujuan yang menjadi orientasinya.

\section{Wewenang dan Tanggung ja- wab}

Bahwa dalam mekanisme kerja selalu terjadi bentuk struktur organisasi, yang menunjukkan batas kewenangan dan tanggungjawab masing-masing pegawai. Pemahaman tersebut perlu ada disanubari para pegawai. Mereka mengetahui batas wewenang serta tanggung jawabnya sehingga dalam menjalankan kerja tidak overlapping dan mudah/jelas pertanggungjawabannya. Wewenang artinya kekuasaan atau hak untuk melakukan sesuatu. Sesuatunya tersebut menjadi tanggungjawabnya. Tanggungjawab artinya adanya kesadaran pegawai menanggung segala konsekuensi yang menjadi wewenangnya. Jadi antara wewenang dan tanggungjawab harus seimbang.

\section{Keikhlasan dan kejujuran.}

Rasa ini perlu menjadi dasar dalam bekerja. Adanya ikhlas mem- 
berikan kesediaan bekerja yang tulus tanpa paksaan dan tanpa pam-rih. Kondisi ini memberikan suasa-na batin menjadi fidak terbebani. Kejujuran mengandung arti melakukaan kerja apa adanya, tidak rekayasa baik dari sisi waktu, proses, pisik/produk maupun terkait dengan permasalahan keuangan. Kondisi moral ini harus tertanan dalam sanubari masing-masing aparatur supaya ketika mereka melayani masyarakat tidak ada keterpaksaan seshingga menampakan kejernihan dalam wajahnya.

\section{Integritas dan profesional}

Kata integritas berarti keteguhan hati untuk melakukan komitmen yang telah menjadi kesepakatan bersama. Profesional artinya melakukan pekerjan dengan berpedoman pada kualitas' profesi yang menjadi sarat kualifikasi/kompetensi dari profesi masing-masing. Profesional berarti dalam melakukan pekerjaan mengacu pada hasil yang optimal, dengan kata lain pegawai mampu menjalankan kerja yang berkualitas sesuai dengan tuntutan keahliannya. Kesatuan integritas dan profesional merupakan paduan yang saling mendukung dalam meningkatkan kualitas pekerjaan.

\section{Keadilan dan keterbukaan}

Mengandung arti bahwa ketika apartatur pemerintah menjalankan pekerjaan sehari-hari, melakukan pelayanan kepada publik perlu bertindak adil terhadap semua pihak, tidak membedakan dengan nepotisme-ya (menempatkan sesuai dengan aturan main/prosedurnya) dan semuanya dengan cara transpaansi, penun keterbukaan sehingga semua pihak dapat dengan aman untuk mengetahui informasi yang diinginkannya.

Adanya kesasadaran akan nilai-nilai di atas akan memberikan arahan dalam proses melakukan pekerjaan di kantor. Tentu saja hal tersebut perlu dihayati secara mendalam dan terus menerus selalu eksis dalam suasana kerja. Satu permasalahan terkait dengan nilai-nilai moral di atas mungkin tidak berhenti pada penjiwaan suasana hati dan angan-angan saja akan tetapi harus direalisasikan dalam proses kerja. Adanya teguran dari pimpinan ataupun teman sejawat tidak menjadikan sakit hati dan frustasi tetapi menimbulkan kesadaran baru untuk melakukan yang lebih baik sesuai tuntutan moral sesuai dengan misi/ visi lembaga. Komitmen tersebut harus dibangur, dalam suasana kerja terutama adalah kepedulian pimpinan untuk selalu mengeksiskana dalam sauasana kerja.

\section{Penutup}

Untuk membangun kinerja yang profesional bagi pegawai di lingkungan organisasi publik, tidak saja himbauan untuk melakukan pekerjaan sebagaimana idealisme dalam keputusan Menpan Keputu- 
san Menteri PAN No. 25/Kep/ M.Pan/4/2002 tentang Pedoman Pengembangan Budaya Kerja Aparatur Negara, akan tetapi nampaknya per'u reevaluasi terhadap mekanisme pelaksanaan Daftar Penilaian Pelaksanaan Pekerjaan (DP3), yang selama ini terkesan formalitas serta tidak mampu memberikan semangat pegawai untuk meningkatkan kinerja seperti yang diamanatkan dalam UU No.8 tahun 1974. Pemberian penilaian tersebut harus mampu memberikan stimulus dan berdampak positif untuk kompetitif pegawai dalam meningkatkan kualitas diri. Di sisi lain juga memperhatikan pemberian penghargaan yang fungsional untuk pemacu dalam meningkatkan produktivitas pegawai. Untuk itu perlu menerapakn konsep pemberian penghargaan, yang meliputi: adanya extemal equity, internal equity dan Individual Equity.
Daftar Pustaka

Keputusan Menteri PAN No. 25/Kep/M.Pan/4/2002 tentang Pedoman Pengembangan Budaya Kerja Aparatur Negara

Wahyudi Kumorotomo, 1992. Etika Administrasi Negara. Jakarta: Radja Grafindo Persada

PP RI No. 10 tahun 1974 tentang penilaian pelaksanaan pekerjaan PNS

UU No.8 tahun 1974 tentang Pokok-Pokok Kepegawaian

\section{Biodata Penulis}

Nama lengkap penulis adalah Rosidah, salah satu staf pengajar pada Jurusan Pendidikan Administrasi Fakultas limu Sosial dan Ekonomi, Universitas Negeri Yogyakarta 